\title{
Conjugation Enhancement of Intramolecular Exciton Migration in Poly(p-phenylene
}

\author{
ethynylene)s \\ Evgueni E. Nesterov, Zhengguo Zhu and Timothy M. Swager* \\ Department of Chemistry and Institute for Soldier Nanotechnologies, Massachusetts Institute of \\ Technology, Cambridge, MA 02139
}

\section{Supporting Information}

General Procedures. All reactions were performed under an atmosphere of dry nitrogen. Melting points were determined in open capillaries and are uncorrected. Column chromatography was performed on silica gel (SiliCycle Inc., $60 \AA \AA$, 40-63 $\mu \mathrm{m}$ ) slurry packed into glass columns. All solvents were additionally purified and dried by standard techniques. Liquid crystal, 1-(trans-4hexylcyclohexyl)-4-isothiocyanatobenzene (6CHBT) was purchased from Aldrich Chemical Co., Inc. High purity $\mathrm{Pd}\left(\mathrm{PPh}_{3}\right)_{4}$ and CuI were obtained from Strem Chemicals, Inc. 1,4-Bis(2-ethylhexyl)-2,5diiodobenzene was prepared according to literature procedure, ${ }^{1}$ and also can be purchased from Aldrich (cat. No. 63,671-1). Synthesis of 2,6-di-tert-butylanthracene has been previously reported. ${ }^{2}$ All other reagents were obtained from Aldrich and Alfa Aesar and used without further purification. ${ }^{1} \mathrm{H}$ and ${ }^{13} \mathrm{C}$ NMR spectra were recorded at $300 \mathrm{MHz}$ and $75 \mathrm{MHz}$ respectively, and are reported in ppm downfield from tetramethylsilane. UV-visible spectra were recorded on Cary $50 \mathrm{UV}$-Vis spectrophotometer. Fluorescence and lifetime studies were carried out with a Spex Fluorolog 2 fluorometer (model FL112, $450 \mathrm{~W}$ xenon lamp) equipped with a phase-modulation unit and a 1935B polarization kit. The fluorescence anisotropy was determined using a standard procedure ${ }^{3}$ and is "G-factor" corrected. Variable temperature fluorescence measurements were performed using a water-heated cell connected to a Neslab RTE-111 thermostat. High resolution mass spectra were obtained at the MIT Department of Chemistry Instrumentation Facility using an electron impact $70 \mathrm{eV}$ source and a peak matching protocol to determine the mass and error range of the molecular ion. 


\section{Tetra-tert-butylpentiptycene diacetylene 2 .}
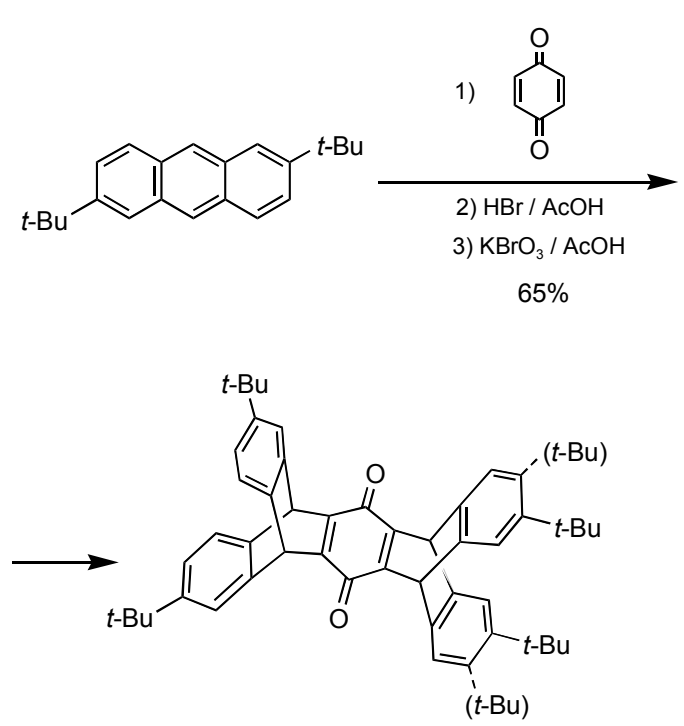

S2

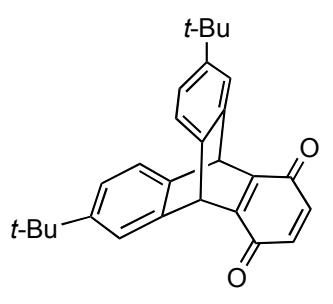

S1

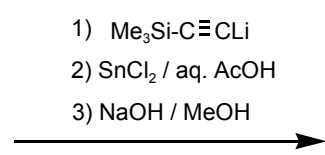

$49 \%$
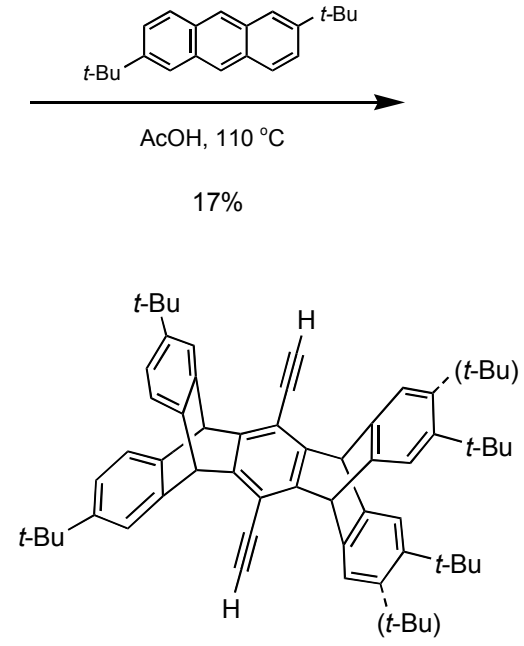

2

6,13-Di-tert-butyl-9,10-dihydro-9,10[1',2']benzenoanthra-1,4-quinone S1. A mixture of $2.50 \mathrm{~g}(8.62 \mathrm{mmol})$ of 2,6-di-tert-butylanthracene and $1.02 \mathrm{~g}(9.48 \mathrm{mmol})$ of benzoquinone in $20 \mathrm{ml}$ of xylenes was heated upon reflux for $3 \mathrm{~h}$. After concentration in vacuo, the dark residue was brought into $16 \mathrm{ml}$ of glacial acetic acid, 1 drop of conc. aqueous $\mathrm{HBr}$ was added, and the resulting mixture was refluxed for $10 \mathrm{~min}$ followed by addition of a solution of $0.72 \mathrm{~g}(4.31 \mathrm{mmol})$ of $\mathrm{KBrO}_{3}$ in $15 \mathrm{ml}$ of water. The reaction mixture was refluxed for another $5 \mathrm{~min}$, allowed to cool to room temperature, water $(10 \mathrm{ml})$ was added, and the solid precipitate was filtered, successively washed with acetic acid and water, then redissolved in $\mathrm{CHCl}_{3}$, washed with saturated solution of $\mathrm{NaHCO}_{3}$, water, and dried over $\mathrm{Na}_{2} \mathrm{SO}_{4}$. Concentration in vacuo afforded a dark residue which was separated by chromatography on silica gel (column 31.0_5.0 cm, eluent ethyl acetate - hexane 1:9). A fraction with $R_{f} 0.71$ afforded the crude product as a yellow oil, solidifying upon standing. It was additionally recrystallized from $\mathrm{CH}_{2} \mathrm{Cl}_{2}$ - hexane mixture to give $2.20 \mathrm{~g}(65 \%)$ of $\mathbf{S 1}$ as a yellow crystalline material, mp $255-258{ }^{\circ} \mathrm{C} .{ }^{1} \mathrm{H} \mathrm{NMR}$ $\left(\mathrm{CDCl}_{3}\right) \delta 7.45(\mathrm{~d}, J=1.8 \mathrm{~Hz}, 2 \mathrm{H}), 7.34(\mathrm{~d}, J=7.5 \mathrm{~Hz}, 2 \mathrm{H}), 7.04\left(\mathrm{dd}, J_{l}=7.5, J_{2}=1.8 \mathrm{~Hz}, 2 \mathrm{H}\right), 6.58$ (s, 2H), 5.73 (s, 2H), 1.26 (s, 18H). HRMS m/e 396.2074 (calcd for $\mathrm{C}_{28} \mathrm{H}_{28} \mathrm{O}_{2}$ 396.2084).

Tetra-tert-butylpentiptycene quinone S2. To a stirred at reflux condition suspension of $0.48 \mathrm{~g}$ (1.68 mmol) of 2,6-di-tert-butylanthracene in $10 \mathrm{ml}$ of glacial acetic acid, quinone 2 (1.00 g, 2.52 mmol) was added in small portions over period of $4 \mathrm{~h}$. After $6 \mathrm{~h}$ an additional portion of 2,6-di-tertbutylanthracene $(0.48 \mathrm{~g}, 1.68 \mathrm{mmol})$ was added, and the refluxing was continued for another $30 \mathrm{~h}$. At this point, another portion of $2(0.50 \mathrm{~g}, 1.26 \mathrm{mmol})$ was added, and the reaction mixture was refluxed for additional $30 \mathrm{~h}$. After being allowed to cool to room temperature, the reaction mixture was poured 
into water, the solid precipitate was filtered, washed with water, and dried in vacuo. It was subjected to chromatography on silica gel (column 33.0_5.0 cm, eluent ethyl acetate - hexane 1:9), and a fraction with $R_{f} 0.85$ was collected which afforded $0.60 \mathrm{~g}$ of an orange solid. According to ${ }^{1} \mathrm{H}$ NMR, this was a mixture of 3 and starting 2,6-di-tert-butylanthracene in an approximate ratio 1:1, that was further separated by chromatography on silica gel (column $15.0 \_4.0 \mathrm{~cm}$ ). It was first eluted with hexane until no anthracene was detected by TLC, followed by eluting with ethyl acetate - hexane 1:9 which afforded $0.45 \mathrm{~g}$ of crude $\mathbf{S 2}$. Recrystallization from pentane gave $0.38 \mathrm{~g}(17 \%)$ of pure $\mathbf{S 2}$ as an orange crystalline material, $\mathrm{mp}>390{ }^{\circ} \mathrm{C}$ (dec.). ${ }^{1} \mathrm{H}$ NMR $\left(\mathrm{CDCl}_{3}\right) \delta 7.38(\mathrm{~d}, J=1.8 \mathrm{~Hz}, 4 \mathrm{H}), 7.26(\mathrm{~d}, J=7.8$ $\mathrm{Hz}, 4 \mathrm{H}), 6.97\left(\mathrm{dd}, J_{1}=7.8, J_{2}=1.8 \mathrm{~Hz}, 4 \mathrm{H}\right), 5.68(\mathrm{~s}, 4 \mathrm{H}), 1.21(\mathrm{~s}, 36 \mathrm{H}) .{ }^{13} \mathrm{C} \mathrm{NMR}\left(\mathrm{CDCl}_{3}\right) \delta 180.56$, $151.45,148.78,143.95,140.97,123.75,122.05,121.86,47.42,34.75,31.61$. HRMS m/e 684.3956 (calcd for $\mathrm{C}_{50} \mathrm{H}_{52} \mathrm{O}_{2}$ 684.3962).

Tetra-tert-butylpentiptycene diacetylene 2 . A solution of $n$ - $\mathrm{BuLi}(0.56 \mathrm{ml}$ of $1.6 \mathrm{M}$ solution in hexanes, $0.90 \mathrm{mmol})$ was added dropwise to a stirred at $0{ }^{\circ} \mathrm{C}$ solution of $0.088 \mathrm{~g}(0.126 \mathrm{ml}, 0.90$ mmol) of (trimethylsilyl)acetylene in $10 \mathrm{ml}$ of THF. The resulting solution was stirred for $1 \mathrm{~h}$ at $0{ }^{\circ} \mathrm{C}$, followed by dropwise addition of a solution of $0.15 \mathrm{~g}(0.22 \mathrm{mmol})$ of $\mathbf{S 2}$ in $2 \mathrm{ml}$ of THF. The reaction mixture was stirred for $30 \mathrm{~min}$ at $0{ }^{\circ} \mathrm{C}$ and further stirred at room temperature for $16 \mathrm{~h}$. Then it was poured into conc. $\mathrm{NH}_{4} \mathrm{Cl}$ solution, extracted with ether, the organic fraction was successively washed with water, brine, and dried over $\mathrm{Na}_{2} \mathrm{SO}_{4}$. Concentration in vacuo afforded a crude mixture of stereoisomeric alcohols as a colorless solid. It was dissolved in $20 \mathrm{ml}$ of acetone, and a solution of $0.113 \mathrm{~g}(0.50 \mathrm{mmol})$ of $\mathrm{SnCl}_{2}{ }_{2} \mathrm{H}_{2} \mathrm{O}$ in $2 \mathrm{ml}$ of $50 \%$ aqueous acetic acid was added dropwise to the stirred acetone solution at room temperature. The reaction mixture was stirred for $24 \mathrm{~h}$, then diluted with water, extracted with ether, the organic fraction was washed successively with water, conc. $\mathrm{NaHCO}_{3}$, water, and brine, and dried over $\mathrm{Na}_{2} \mathrm{SO}_{4}$. Concentration in vacuo gave $0.54 \mathrm{~g}$ of a crude disilyl-protected $\mathbf{2}$ as a yellowish solid material. For deprotecting, it was dissolved in $3 \mathrm{ml}$ of THF, and added dropwise to a stirred solution of $0.044 \mathrm{~g}(1.10 \mathrm{mmol})$ of $\mathrm{NaOH}$ in $10 \mathrm{ml}$ of methanol. The resulting solution was stirred at room temperature for $1 \mathrm{~h}$, poured into water and extracted with ether. The organic fraction was successively washed with water, conc. $\mathrm{NH}_{4} \mathrm{Cl}$ solution, brine, and dried over $\mathrm{Na}_{2} \mathrm{SO}_{4}$. After concentration in vacuo, the crude product as a yellow solid was purified by chromatography on silica gel (column 21.0_1.5 cm, eluent ethyl acetate - hexane 1:9), and a fraction with $R_{f} 0.77$ was collected and afforded, after recrystallization from pentane, $0.075 \mathrm{~g}(49 \%)$ of 2 as a colorless crystalline material, $\mathrm{mp}>390{ }^{\circ} \mathrm{C}$ (dec.). ${ }^{1} \mathrm{H} \mathrm{NMR}\left(\mathrm{CDCl}_{3}\right) \delta 7.35(\mathrm{~s}, 4 \mathrm{H}), 7.25(\mathrm{~d}, \mathrm{~J}=7.8 \mathrm{~Hz}$, 4H), $6.92(\mathrm{~d}, \mathrm{~J}=7.8 \mathrm{~Hz}, 4 \mathrm{H}), 5.74(\mathrm{~s}, 4 \mathrm{H}), 3.68(\mathrm{~s}, 2 \mathrm{H}), 1.21(\mathrm{~s}, 36 \mathrm{H}) .{ }^{13} \mathrm{C} \mathrm{NMR}\left(\mathrm{CDCl}_{3}\right) \delta 148.19$ 
(2C), 148.18 (2C), 144.81 (4C), 142.02 (2C), 141.97 (2C), 123.15 (2C), 123.06 (2C), 121.78 (2C), 121.74 (2C), 121.16 (2C), 121.07 (2C), 113.79 (2C), 99.78 (4C), 84.27 (2C), 84.22 (2C), 79.39 (2C), 51.82 (2C), 34.51 (4C), 31.46 (12C). HRMS m/e 702.4213 (calcd for $\mathrm{C}_{54} \mathrm{H}_{54} 702.4220$ ).

\section{9-Ethynyl-10-(Phenylethynyl)anthracene 4.}

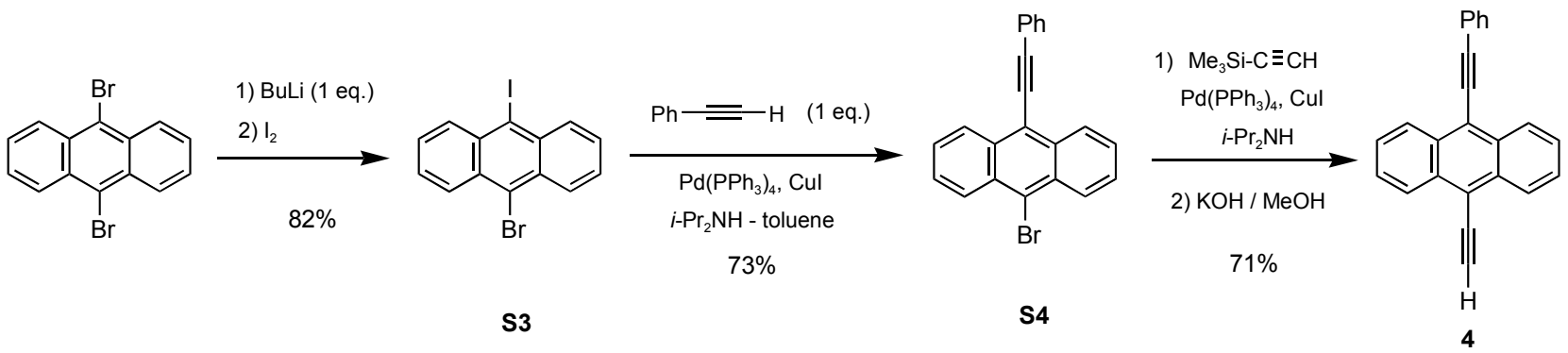

9-Bromo-10-iodoanthracene S3. A solution of $n$-BuLi $(20.1 \mathrm{ml}$ of $1.6 \mathrm{M}$ solution in hexanes, $32.1 \mathrm{mmol})$ was added dropwise to a stirred at $-70{ }^{\circ} \mathrm{C}$ suspension of $10.0 \mathrm{~g}(29.8 \mathrm{mmol})$ of 9,10dibromoanthracene in $200 \mathrm{ml}$ of THF, and the resulting mixture was stirred for $3 \mathrm{~h}$ at this temperature. To the resulting clear red solution a solution of $9.78 \mathrm{~g}(38.5 \mathrm{mmol})$ of iodine in $50 \mathrm{ml}$ of THF was added dropwise, and after the addition was complete, the reaction mixture was stirred for $1 \mathrm{~h}$ at $-70{ }^{\circ} \mathrm{C}$, and then allowed to warm to room temperature overnight. The resulting mixture was concentrated in vacuo to approximately $10 \%$ of the initial volume, and $20 \%$ aqueous solution of $\mathrm{Na}_{2} \mathrm{~S}_{2} \mathrm{O}_{3}$ was added. A yellow crystalline precipitate was filtered, washed successively with dilute $\mathrm{Na}_{2} \mathrm{~S}_{2} \mathrm{O}_{3}$ solution, water, and cold ethanol, and dried in vacuo. Recrystallization from toluene afforded $9.3 \mathrm{~g}(82 \%)$ of $\mathbf{S 3}$ as yellow fiber-like crystals, $\mathrm{mp} 219-220{ }^{\circ} \mathrm{C} .{ }^{1} \mathrm{H}$ NMR $\left(\mathrm{CDCl}_{3}\right) \delta 8.64-8.52(\mathrm{~m}, 4 \mathrm{H}), 7.68-7.56(\mathrm{~m}$, 4H). HRMS m/e 381.8839 (calcd for $\mathrm{C}_{14} \mathrm{H}_{8} \mathrm{BrI} 381.8846$ ).

9-Bromo-10-phenylethynylanthracene S4. A mixture of $6.0 \mathrm{~g}(15.67 \mathrm{mmol})$ of S3, $1.60 \mathrm{~g}$ $(1.72 \mathrm{ml}, 15.66 \mathrm{mmol})$ of phenylacetylene, $0.060 \mathrm{~g}(0.313 \mathrm{mmol})$ of CuI, and $0.361 \mathrm{~g}(0.313 \mathrm{mmol})$ of $\mathrm{Pd}\left(\mathrm{PPh}_{3}\right)_{4}$ in $100 \mathrm{ml}$ of toluene $-i$ - $\mathrm{Pr}_{2} \mathrm{NH}(7: 3)$ mixture was stirred in a sealed flask at $55^{\circ} \mathrm{C}$ for $24 \mathrm{~h}$. The reaction mixture was allowed to cool to room temperature, $\mathrm{CH}_{2} \mathrm{Cl}_{2}(200 \mathrm{ml})$ was added, and the mixture was stirred until all solid dissolved, then washed with water, and dried over $\mathrm{Na}_{2} \mathrm{SO}_{4}$. Concentration in vacuo afforded yellow solid, which was recrystallized from toluene to afford $4.1 \mathrm{~g}$ $(73 \%)$ of $\mathbf{S 4}$ as a yellow crystalline material, mp $170-171{ }^{\circ} \mathrm{C}$ (lit. $\left.{ }^{4} \mathrm{mp} 168^{\circ} \mathrm{C}\right)$. The spectral properties were in agreement with the literature data. ${ }^{4}$

9-Ethynyl-10-(phenylethynyl)anthracene 4. A mixture of $0.53 \mathrm{~g}(1.48 \mathrm{mmol})$ of $\mathbf{S 4}, 0.44 \mathrm{~g}$ $(0.63 \mathrm{ml}, 4.44 \mathrm{mmol})$ of (trimethylsilyl)acetylene, $17.1 \mathrm{mg}(0.089 \mathrm{mmol})$ of CuI and $102.7 \mathrm{mg}(0.089$ mmol) of $\mathrm{Pd}\left(\mathrm{PPh}_{3}\right)_{4}$ in $10 \mathrm{ml}$ of toluene $-i$ - $\mathrm{Pr}_{2} \mathrm{NH}(7: 3)$ mixture was stirred at $80{ }^{\circ} \mathrm{C}$ in a sealed flask 
for $36 \mathrm{~h}$. After allowing to cool to room temperature, the reaction mixture was diluted with chloroform and passed through a short column with silica gel eluted with chloroform. After concentrating in vacuo, the oily residue was dissolved in ethyl acetate - hexane (1:9) mixture and passed through a column with silica gel (column 17.0x2.5 cm) eluted with the same solvent. Concentration in vacuo afforded a crude product as a dark-red crystalline material. It was dissolved in $40 \mathrm{ml}$ of THF and added dropwise into a stirred solution of $0.25 \mathrm{~g}(4.44 \mathrm{mmol})$ of $\mathrm{KOH}$ in $100 \mathrm{ml}$ of methanol. The resulting mixture was stirred at room temperature for $40 \mathrm{~min}$, poured into water, extracted with ether, the organic fraction was washed successively with water, conc. $\mathrm{NH}_{4} \mathrm{Cl}$ solution, water and brine, and dried over $\mathrm{Na}_{2} \mathrm{SO}_{4}$. Concentration in vacuo afforded a solid material, which was dissolved in ethyl acetate - hexane (1:3) mixture and passed through a short column with silica gel. After concentration in vacuo, the product was recrystallized from hexane $-\mathrm{CH}_{2} \mathrm{Cl}_{2}$ mixture to afford $0.32 \mathrm{~g}(71 \%)$ of 4 as orange needle-like crystals, decomposing upon heating to $130-135{ }^{\circ} \mathrm{C}$ (lit. ${ }^{5} \mathrm{mp} 170{ }^{\circ} \mathrm{C}$ (dec.)). ${ }^{1} \mathrm{H} \mathrm{NMR}\left(\mathrm{CDCl}_{3}\right) \delta 8.72-$ $8.68(\mathrm{~m}, 2 \mathrm{H}), 8.65-8.60(\mathrm{~m}, 2 \mathrm{H}), 7.78\left(\mathrm{dd}, J_{1}=7.0, J_{2}=2.0 \mathrm{~Hz}, 2 \mathrm{H}\right), 7.66-7.61(\mathrm{~m}, 4 \mathrm{H}), 7.49-7.40$ (m, 3H), 4.09 (s, 1H). HRMS m/e 302.1091 (calcd for $\mathrm{C}_{24} \mathrm{H}_{14} 302.1090$ ).

\section{Polymer 1.}

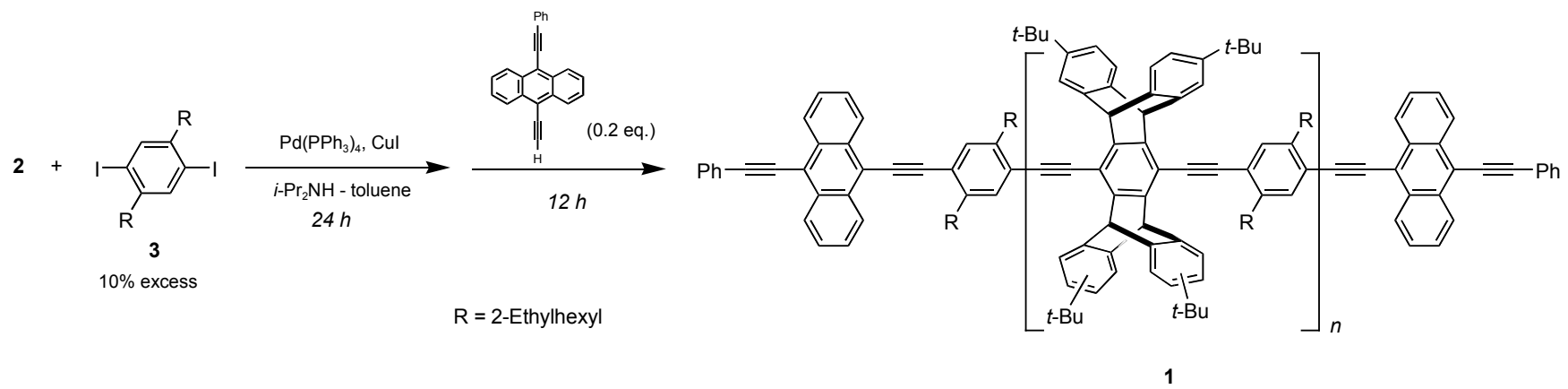

A mixture of $58.0 \mathrm{mg}(0.105 \mathrm{mmol})$ of 1,4- bis(2-ethylhexyl)-2,5-diiodobenzene 3, $66.7 \mathrm{mg}$ $(0.095 \mathrm{mmol})$ of $2,0.92 \mathrm{mg}(0.0048 \mathrm{mmol})$ of $\mathrm{CuI}$, and $5.54 \mathrm{mg}(0.0048 \mathrm{mmol})$ of $\mathrm{Pd}\left(\mathrm{PPh}_{3}\right)_{4} \mathrm{was}$ loaded into a Schlenk flask, which was degassed and back-filled with argon. Solvent (2.5 $\mathrm{ml}$ of $i$ $\operatorname{Pr}_{2} \mathrm{NH}$ - toluene (3:7) mixture) was added, the flask was sealed, and the reaction mixture was stirred at $90{ }^{\circ} \mathrm{C}$ for $24 \mathrm{~h}$. Then it was allowed to cool to room temperature, a solution of $6.34 \mathrm{mg}(0.021 \mathrm{mmol})$ of 4 in $1 \mathrm{ml}$ of $i-\operatorname{Pr}_{2} \mathrm{NH}$ - toluene mixture was added, the flask was resealed and the reaction mixture was stirred at $90{ }^{\circ} \mathrm{C}$ for additional $12 \mathrm{~h}$. The reaction mixture was cooled to room temperature, diluted with chloroform, and passed through a short column with silica gel using chloroform as an eluent. After concentrating in vacuo, the residue was redissolved in a small volume of chloroform and added into stirred methanol. The precipitate was separated, washed twice with hot acetone, and dried in 
vacuo. This afforded $55 \mathrm{mg}(58 \%)$ of the polymer as an orange powder. It was further purified by column chromatography on silica gel as described below. The crude polymer was absorbed on silica gel by concentrating in vacuo a solution of the polymer in $\mathrm{CH}_{2} \mathrm{Cl}_{2}$ mixed with silica gel. The resulting material was loaded on top of a small column with silica gel, which was first eluted with acetone until the colorless outcome, followed by elution with $\mathrm{CH}_{2} \mathrm{Cl}_{2}$. After concentration in vacuo the $\mathrm{CH}_{2} \mathrm{Cl}_{2}$ fraction afforded pure 1 as an orange solid. ${ }^{1} \mathrm{H}$ NMR $\left(\mathrm{CDCl}_{3}\right) \delta 8.9-8.65(\mathrm{~m}, 0.34 \mathrm{H}$, corresponds to 8 protons of the end-capping groups), 7.84 (br. s, 2H), 7.47 (br. s, 4H), 7.38 (br. s, 4H), $7.15-6.90$ (m, 4H), $6.10-5.80$ (m, 4H), $3.38-3.10$ (br. s, 4H), $2.10-2.00$ (br. s, 2H), $1.85-1.00$ (m, 58H), $0.75-$ $0.60(\mathrm{~m}, 6 \mathrm{H})$. From the ${ }^{1} \mathrm{H}$ NMR end-group analysis degree of polymerization was determined to be approximately 23. GPC analysis: $M_{n} 24500 \mathrm{Da}$, PDI 1.69 .

Polymer 5. The phenyl end-capped polymer 5 was prepared according to the procedure for polymer 1 , with phenylacetylene used instead of the end-capping reagent 4 . Reaction of $33.0 \mathrm{mg}(0.060$ mmol) of diiodo monomer 3, $44.2 \mathrm{mg}(0.063 \mathrm{mmol})$ of 2, $0.67 \mathrm{mg}(0.0035 \mathrm{mmol})$ of CuI, $4.04 \mathrm{mg}$ $(0.0035 \mathrm{mmol})$ of $\mathrm{Pd}\left(\mathrm{PPh}_{3}\right)_{4}$ in $3 \mathrm{ml}$ of $i-\mathrm{Pr}_{2} \mathrm{NH}$ - toluene $(3: 7)$ mixture for $60 \mathrm{~h}$ at $80{ }^{\circ} \mathrm{C}$, followed by addition of $0.1 \mathrm{ml}(0.91 \mathrm{mmol})$ of phenylacethylene and further stirring at $80{ }^{\circ} \mathrm{C}$ for $24 \mathrm{~h}$ afforded, after work-up, $30 \mathrm{mg}(50 \%)$ of $\mathbf{5}$ as a yellow solid. The ${ }^{1} \mathrm{H}$ NMR spectrum was similar to one for the polymer 1. GPC analysis: $M_{n} 26500 \mathrm{Da}, P D I 1.80$.

Preparation of $0.05 \%$ solution of 1 in 6CHBT. A stock solution of polymer 1 in chloroform (concentration $0.02 \mathrm{mg} / \mathrm{ml}$ ) was prepared. A $2.5 \mathrm{ml}$ aliquot was taken and added to $100 \mathrm{mg}$ of 6CHBT in a round-bottom flask. The clear solution was concentrated in vacuo, which resulted in a homogenous LC solution. It was loaded at $60{ }^{\circ} \mathrm{C}$ into a KSRT-10 test cell (cell gap $10 \mu \mathrm{m}$, with parallel rubbed polyimide coating, manufactured by E.H.C. Co. Ltd, Japan) which was placed into a Linkham 350 Hot Stage apparatus with a temperature controller. The cell was slowly cooled to $45^{\circ} \mathrm{C}$ and equilibrated at this temperature for $40 \mathrm{~min}$, then slowly cooled to room temperature.

Quantum yield determinations. The fluorescence quantum yields were determined relative to quinine bisulfate in $1.0 \mathrm{~N} \mathrm{H}_{2} \mathrm{SO}_{4}$ (solution samples, $\Phi=0.55^{6}$ ), and $\sim 1 \mathrm{mM} \mathrm{9,10-diphenylanthracene}$ in PMMA spin-cast film (solid films, $\Phi=0.83^{7}$ ). Absorption spectra and quantum yield determination for the LC solution samples were carried out on the solution placed in a KSSZ-50 glass test cell (cell gap $50 \mu \mathrm{m}$ ). The quantum yield was determined relative to a $\mathrm{CHCl}_{3}$ solution of the polymer 1 placed into the same cell.

Aggregation studies. A $30 \mu \mathrm{l}$ aliquot of stock solution of polymer $\mathbf{1}$ in $\mathrm{CHCl}_{3}$ was added to volumetric flasks containing $5.0 \mathrm{ml}$ of mixtures of $\mathrm{CHCl}_{3}$ and methanol with the variable fraction of 
methanol ranging from 0 to $100 \%$. The concentration of the stock solution of $\mathbf{1}$ was chosen to get optical density at maximum absorption of the final solutions below 0.1 . The resulting solutions were ultrasonicated for $5 \mathrm{~min}$ at room temperature, and their absorption and fluorescence spectra were recorded.

Energy transfer efficiency determination. The energy transfer efficiency was estimated by comparison of emission spectra of the anthracene end-capped polymer 1 and the phenyl end-capped model polymer 5. The comparison was done separately for each environment studied $\left(\mathrm{CH}_{2} \mathrm{Cl}_{2}\right.$ and $\mathrm{LC}$ solutions, spin-cast film). The emission spectra were normalized to constant absorption at the excitation wavelength $(370 \mathrm{~nm})$. An example of such treatment (case of isotropic $\mathrm{CH}_{2} \mathrm{Cl}_{2}$ solution) is shown in Figure S1. The energy transfer efficiency was calculated as a ratio of the anthracene endgroup emission integral intensity (shaded area in Figure S1, corrected by the end-group emission quantum yield $0.87^{8}$ ) to the total emission area of the phenyl end-capped polymer $\mathbf{5}$. This approach is justified in this case as the anthracenyl end group has substantially no absorbance at the PPE excitation wavelength $(370 \mathrm{~nm})$, therefore its emission is unlikely to occur from the direct excitation. Instead, it comes purely as a result of energy transfer from the PPE backbone, thus serving as a measure of the efficiency of this process. We chose this method over the more traditional approach based on

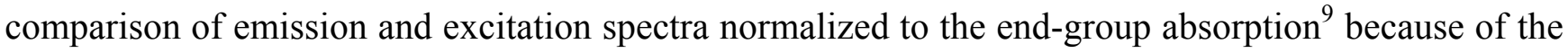
very low end-group absorbance in the systems studied (especially in very dilute LC solutions), that would lead to bigger measurement errors.

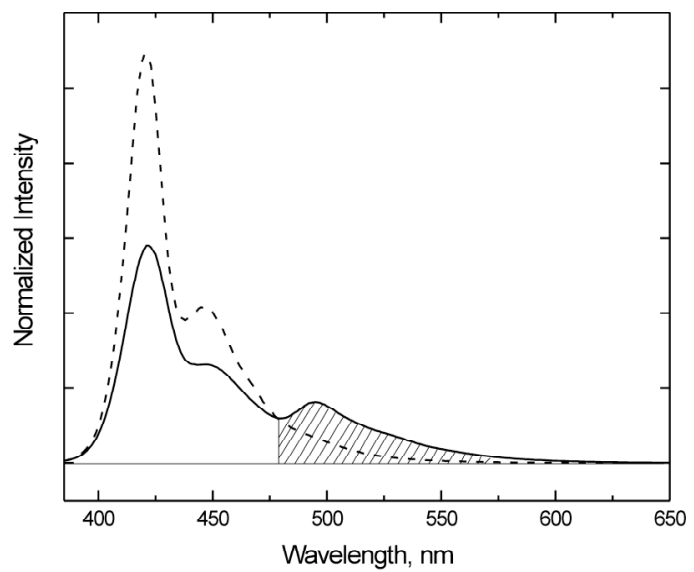

Figure S1. Emission spectra of polymer 1 (solid line), and model polymer 5 (dashed line) in $\mathrm{CH}_{2} \mathrm{Cl}_{2}$ solution. The spectra are normalized to constant absorption at the excitation wavelength $(370 \mathrm{~nm})$. 


\section{Additional Figures.}

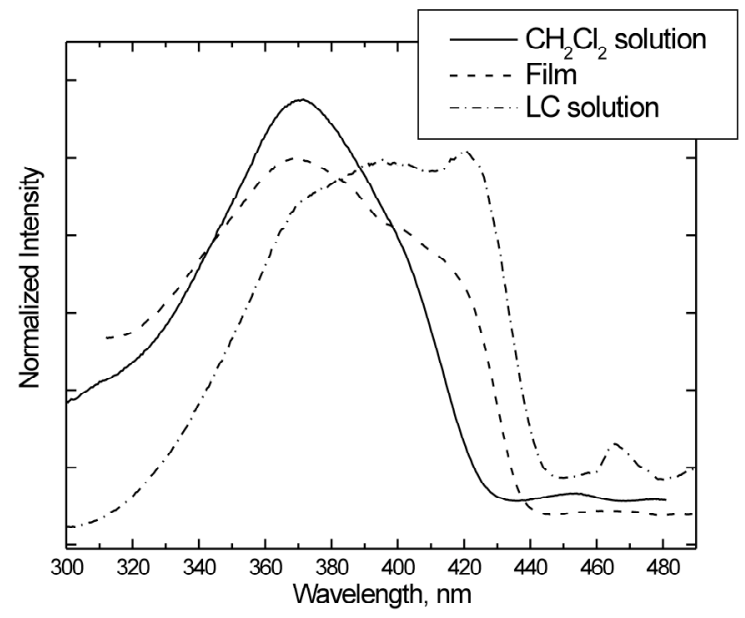

Figure S2. Normalized excitation spectra of polymer 1. The spectra were recorded under the detection of anthracenyl emission at $500 \mathrm{~nm}$.

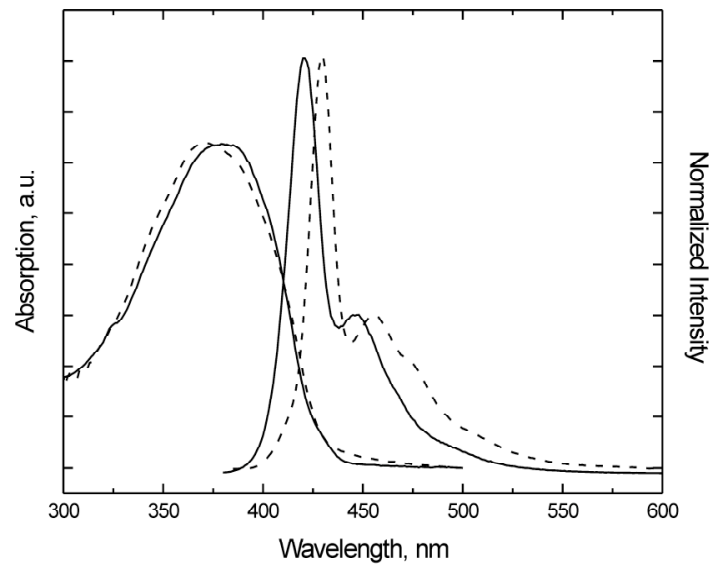

Figure S3. Absorption and fluorescence spectra of model polymer $\mathbf{5}$ in $\mathrm{CH}_{2} \mathrm{Cl}_{2}$ (solid line) and LC (dashed line) solutions.

\section{References.}

(1) Kloppenburg, L.; Song, D.; Bunz, U. H. F. J. Am. Chem. Soc. 1998, 120, 7973-7974.

(2) (a) Lacowicz, J. R. Principles of Fluorescence Spectroscopy, Second Edition, Kluwer Academic / Plenum, New York, 1999; (b) a detailed description of the experiment is given in Supporting 
information to: Breen, C. A.; Deng, T.; Breiner, T.; Thomas, E. L.; Swager, T. M. J. Am. Chem. Soc. 2003, 125, 9942-9943.

(3) Fu, P. P.; Harvey, R. G. J. Org. Chem. 1977, 42, 2407-2410.

(4) Swager, T. M.; Gil, C. J.; Wrighton, M. S. J. Phys. Chem. 1995, 99, 4886-4893.

(5) Skowronski, R.; Chodkiewicz, W.; Cadiot, P. Bull. Soc. Chim. Fr. 1967, 4235-4243.

(6) Olmsted, III, J. J. Phys. Chem. 1979, 83, 2581-2584.

(7) Osaheni, J. A.; Jenekhe, S. A. J. Am. Chem. Soc. 1995, 117, 7389-7398.

(8) Levitus, M.; Garcia-Garibay, M. A. J. Phys. Chem. A 2000, 104, 8632-8637.

(9) (a) Devadoss, C.; Bharathi, P.; Moore, J. S. J. Am. Chem. Soc. 1996, 118, 9635-9644; (b) Gust, D.; Moore, T. A.; Moore, A. L.; Devadoss, C.; Liddell, P. A.; Hermant, R.; Nieman, R. A.; Demanche, L. J.; DeGraziano, J. M.; Gouni, I. J. Am. Chem. Soc. 1992, 114, 3590-3603. 